\title{
STRATEGI KEGIATAN BELAJAR MENGAJAR DI MASA PANDEMI COVID-19 DI SD NEGERI 36 KOTA BENGKULU
}

${ }^{1}$ Rozali Toyib, ${ }^{2}$ Muntahana , ${ }^{3}$ Rahmad Afriandi, ${ }^{4}$ Fira Rahmadhini, ${ }^{5}$ Yusi Isnadia, ${ }^{6}$ Afrinando Kusnadi

${ }^{123456)}$ Program Studi Teknik Informatika, Fakultas Teknik, Universitas Muhammadiyah Bengkulu *Corresponding author: rozalitoyib@umb.ac.id

Informasi Artikel

Terima : 05/03/2021

Revisi : 22/05/2021

Disetujui : 02/08/2021

Kata Kunci: Guru, kegiatan belajar mengajar, covid 19 , daring

\begin{abstract}
ABSTRAK
Pandemi Covid 19 yang timbul di pertengan Maret 2020 menyebabkan ada perubahan dalam tata cara mengajar yang biasanya lewat tatap muka menjadi pembelajaran daring menimbulkan permasalahan yang besar bagi guru-guru yang telah terbiasa dengan metode lama serta adanya perubahan dan petunjuk teknis dari mendikbud yang mewajibkan guru-guru melakukan kegiatan belajar mengajar via online lewat jaringan internet dimana proses pembelajarannya langsung berhadapan dengan sistem yang membuat sebagian besar guru yang sudah senior yang Gaptek menjadi kesusahan dalam proses ini dan keterabatasan penguasahaan teknologi tentu menghambat proses alih ilmu ke siswa. Sikap yang dapat diambil dalam proses belajar mengajar ditengah pandemic Covid 19, ada 3 solusi yang ditawarkan pada pengabdian kali ini yaitu penggunaan media belajar yaitu google classroom, menggunakan metode belajar yang terstruktur sesuai dengan kondisi pandemic Covid 19, menggunakan bahan ajar yang interaktif dan berbentuk digital untuk memudahkan dalam belajar daring. penggunaan metode Pada Pengabdian Kepada Masyarakat ini, Antusias yang tinggi dari peserta dalam mengikuti kegiatan ini dan partisifasi dari sekolah dengan meluangkan waktu dan prasarna untuk kegiatan, Sosialisasi penggunaan Google Classroom dan media lainnya dapat membantu proses Kegiatan belajar mengajar selama pandemi COVID19 dan perlu penyediaan prasarana yang layak untuk kegiatan ini dan penguatan Jaringan internet disekolah
\end{abstract}

PENDAHULUAN

Sekolah Dasar Negri 36 Kota Bengkulu, berada di Jalan Kenanga 2, Kebun kenanga Kecamatan Ratu Agung Kota Bengkulu, memiliki lahan yang cukup luas dan dilengkapi dengan bangunan-bangunan serta fasilitas penunjang yang lain yang sudah memadai, dan telah banyak meraih prestasi, dibuktikan dengan banyaknya piala yang di pajang rapi di etalase piala ruang kepala sekolah, memiliki fasilitas 
yang baik, dan sebagian besar gurunya rata-rata sudah senior sudah tersertifikasi dan hanya sebagian kecilnya masih muda, selama ini kegiatan belajar mengajar seperti biasa dengan tatap muka antara guru dan anak didik melalui proses pengajaran langsung.

Pandemi Covid 19 yang timbul di pertengan Maret 2020 menyebabkan ada perubahan dalam tata cara mengajar yang biasanya lewat tatap muka menjadi pembelajaran daring menimbulkan permasalahan yang besar bagi guru-guru yang telah terbiasa dengan metode lama serta adanya perubahan dan petunjuk teknis dari mendikbud yang mewajibkan guru-guru melakukan kegiatan belajar mengajar via online lewat jaringan internet dimana proses pembelajarannya langsung berhadapan dengan sistem yang membuat sebagian besar guru yang sudah senior yang Gaptek menjadi kesusahan dalam proses ini dan keterabatasan penguasahaan teknologi tentu menghambat proses alih ilmu ke siswa.

Perubahan baru dalam pembelajaran disekolah-sekolah ini menjadi pekerjaan rumah bagi institusi kementrian pendidikan dan kebudayaan ghampir diseluruh Indonesia, kondisi ini memaksa tenaga pendidikan untuk terbiasa dengan kebiasaan baru yang serba berbauh teknologi dan penggunaan media Komputer, Tuntutan global menuntut dunia pendidikan untuk selalu dan senantiasa menyesuaikan perkembangan teknologi terhadap usaha dalam peningkatan mutu pendidikan, terutama penyesuaian penggunaannya bagi dunia pendidikan khususnya dalam proses pembelajaran. Teknologi informasi merupakan perkembangan sistem informasi dengan menggabungkan antara teknologi komputer dengan telekomunikasi, Institusi pendidikan di Indonesia mulai berlomba-lomba mememanfaatkan Teknologi Informasi dan Komunikasi (TIK) dengan membangun infrastruktur hardware, jaringan internet, pengadaan sofware dan lain sebagainya, yang semua itu dilakukan agar efektif dan efisien. Institusi pendidikan di Indonesia mulai berlomba-lomba mememanfaatkannya.

Teknologi Informasi dan Komunikasi untuk pendidikan dengan membangun infrastruktur hardware, jaringan internet, pengadaan sofware dan lain sebagainya, yang semua itu dilakukan dalam usaha memenuhi kebutuhan akan metode pembelajaran yang lebih efektif dan efisien, pelatihan dengan pemanfaatan aplikasi komputer 
seperti; Intelligent Tutoring System (ITS), Computer Basad Training (CBT), dan e-Learning System(Budiman 2017).

Pengabdian Kepada Masyarakat Ini diharapkan dapat menumbuhkan motivasi besar dari para tenaga pendidik ditengah beragam kesulitan yang mereka hadapi untuk dapat menguasai Teknologi Informasi bagi proses belajar mengajar di kelas untuk menumbuhkan motivasi besar dari para tenaga pendidik ditengah beragam kesulitan yang mereka hadapi untuk dapat menguasainya bagi proses belajar mengajar di kelas adalah: suasana pembelajaran; kemampuan tim dalam menyampaikan pelajaran; penyajian materi; pembelajaran bersifat riil; dan menggunakan teknologi pembelajaran untuk kegiatan (Pudjianto et al. 2020).

Penyusunan bahan ajar oleh guru, diharapkan calon guruguru kita dapat secara mandiri maupun berkelompok berupaya meningkatkan kompetensi, khususnya kompetensi dalam menyusun bahan ajar yang tepat, sesuai kriteria/standar untuk peningkatan kompetensi calon guru bermuara pada peningkatan kompetensi peserta didik sekaligus mencapai tujuan dari pendidikan (Hakim Lukman 2018).

Guru perlu media yang dapat digunakan dalam pembelajaran untuk mengatasi masalah tersebut. Hasil wawancara dengan seluruh guru yang terdiri dari 3 orang, keseluruhannya menyatakan membutuhkan media dalam hal ini multimedia interaktif dalam pembelajaran menyimak. Hasil lain yang terungkap bahwa siswa menyatakan membutuhkan suatu paket program pembelajaran berbantukan komputer multimedia interaktif sebagai alternatif pendukung dalam belajar menyimak. Media pembelajaran yang dapat diulangulang dan dapat digunakan secara mandiri baik di sekolah maupun di rumah. Oleh karena itu, akan dikembangkan bahan ajar interaktif berbantuan komputer(Tulili et al. 2018). Proses pembuatan bahan ajar. Metode pengabdian yang digunakan adalah metode ceramah, simulasi, dan praktik. Kegiatan pengabdian masyarakat ini mendapatkan respon yang positif dari peserta. Di akhir pelatihan, para peserta dapat menciptakan sebuah buku cerita sederhana yang kemudian dapat digunakan dalam proses belajarmengajar di sekolah atau kelas masingmasing peserta. Hal ini dapat dibuktikan dan ditunjukkan dari antusiasme peserta dalam mengikuti kegiatan secara aktif dalam aktivitas bertanya, berdiskusi dan menjawab pertanyaan yang dilontarkan oleh pemateri(Astawa and Utami 2020). 
Internet

(interconnection

networking) adalah seluruh jaringan komputer yang saling terhubung menggunakan standar sistem global Transmission Control Protocol/Internet Protocol Suite (TCP/IP) sebagai protokol pertukaran paket (packet switching communication protocol) untuk melayani miliaran pengguna di seluruh dunia. Sejalan dengan perkembangan budaya manusia, globalisasi informasi berkembang dengan sangat pesat.Dampak dari globalisasi informasi sangat signifikan, baik yang positif maupun yang negatif(Husni, Handayani, and ... 2017).

Virus covid-19 atau coronavirusadalah penyakit yang berasal dari Cina dan para ahli menyatakan bahwa indikasi kuat bahwa penyebab SARS, virus ini penyebab infeksi saluran pernapasan yang menyebar melalui sekresi pernapasan, kemudian hidung pada dinding saluran pernapasan bagian atas, beberapa fakta menyebutkan coronavirus ini menimbulkan banyak kematian, virus ini diduga mengalami mutasi sehingga bersifat semakin ganas(Ainur Risalah et al. 2020).

Pandemik Covid 19 pada awal terjadi Pembatasan Sosial Berskala Besar para guru mengalami kesilitan dalam melakasanakan pembelajaran dari rumah, akhirnya melaksanakan kegiatan Pelatihan Virtual Penjaja (Pembelajaran Jarak Jauh) melalui Zoom Metting/ Webbex hasilnya pendaftar 358 peserta yang mengikuti kegiatan dari tanggal 2 s.d 9 Mei 2020 ternyata 246 peserta Lulus Ujian Pelatihan Virtual. Langkah selanjutnya penulis melakukan monitoring pembelajaran di sekolah binaan Pembelajaran dengan Google Classrom, Google Drive, Google Form, dan Quizziss kemampuan guru dalam dalam melaksanakan Kegiatab Belajar Mengajar sangat meningkat dan berkualitas(Sunarsih, Wijoyo, and Choir 2020). Kondisi pandemi Covid-19 ini mengakibatkan perubahan yang luar biasa, seolah seluruh jenjang pendidikan 'dipaksa' bertransformasi untuk beradaptasi secara tiba-tiba untuk melakukan pembelajaran dari rumah melalui media daring (online). Ini tentu bukanlah hal yang mudah, karena belum sepenuhnya siap. Problematika dunia pendidikan yaitu belum seragamnya proses pembelajaran, baik standar maupun kualitas capaian pembelajaran yang diinginkan(Jaelani et al. 2020).

Pengajaran berbasis online salah satunya yang dituangkan dalam pembuatan dan pemanfaatan blog dapat merangsang minat dari para siswa untuk 
mengakses bahan ajar yang telah dipublikasikan secara online baik informasi berupa text, gambar, audio maupun video pembelajaran yang telah direkam dan diupload oleh guru ke dalam blognya kapan dan dimanapun berada, sehingga akan tercipta pembelajaran berpusat pada siswa (Student Centred Learning) dan tujuan pembelajaran dapat tercapai (Putra, Irawati, and Prijuna 2019).

Pelatihan daring teknologi pembelajaran ini meliputi cara membuat peta konsep dengan iMindMap untuk proses pembelajaran, mengoptimalkan Learning Management System dan Komputasi awan untuk pendidikan (Clouding Computing for Education). Ketiga materi pelatihan daring ini berkaitan erat dalam pembelajaran secara daring dan perlu dipahami oleh guru-guru dan pihak sekolah agar proses pembelajaran dari rumah dapat terlaksana dengan baik dan menghasilkan hasil pembelajaran yang maksimal(Setiawan, Aden, and ... 2020). Tim Transformasi Pendidikan menyelenggarakan dua acara besar untuk membantu guru dalam mempelancar Pembelajaran Jarak Jauh, acara tersebut diantaranya sebagai berikut, Pertama, Rembug Online untuk memetakan permasalahan Guru Sekolah
Dasar dalam pembelajaran daring serta saling berbagi antar sesama guru untuk menyelesaikan permasalahan pembelajaran daring, Kedua, Coaching Online yang dilakukan oleh mahasiswa yang tergabung dalam Tim Transformasi Pendidikan untuk memfasilitasi Guru Sekolah Dasar dalam membuat materi pembelajaran untuk menunjang Kegiatan Belajar Mengajar (Indah and Sari 2021).

Sejak pandemi Covid, pembelajaran daring tidak lagi menjadi pilihan. Daring menjadi kewajiban yang tak terelakkan. Dia menjadi pilihan satu-satunya untuk memastikan pembelajaran berjalan, Surat keputusan 4 menteri terakhir menegaskan bahwa pembelajaran daring di mayoritas wilayah Indonesian bakal diperpanjang sampai akhir tahun. Hal ini tentu menambah tantangan baru bagi setiap pelaku pendidikan di Indonesia. Kewajiban belajar daring ini telah menambah kompleksnya permasalahan pendidikan nasional yang sebelumnya juga sudah kompleks.

Perubahaan pola pembelajaran yang lebih menekankan pada penggunaan media pembelajaran daring menyebabkan banyak perubahan dalam teknis pengerjaan setiap pengajarannya dimana setiap individu diharapkankan mempunyai kemampuan menggunakan 
aplikasi yang terhubung secara online seperti whatsapp, classroom karena sudah tersentralisasi baik itu laporan sekolah, laporan sertifikasi guru dan halhal yang lainnya.

Sikap yang dapat diambil dalam proses belajar mengajar ditengah pandemic Covid 19 adalah yaitu Media, Metode, Materi mendampingi anak dalam menghadapi dunia digital teknologi ada banyak cara. Ada 3 solusi yang ditawarkan pada pengabdian kali ini yaitu sebagai berikut :

1. Media

Pada proses pembelajaran, media pengajaran merupakan wadah dan penyalur pesan dari sumber pesan, dalam hal ini guru, kepada penerima pesan, dalam hal ini siswa, media pengajaran sebagai segala sesuatu yang dapat digunakan untuk merangsang pikiran, perasaan, perhatian, dan kemauan siswa sehingga mendorong terjadinya proses belajar pada diri siswa(suharto 2012). Media pengajaran merupakan wadah dari pesan, materi yang ingin disampaikan adalah pesan pembeajaran dan tujuan yang ingin dicapai adalah proses dalam pembelajaran itu sendiri.Secara umum media mempunyai manfaat memperjelas pesan agar tidak terlalu verbalistis, mengatasi keterbatasan ruang, waktu, tenaga dan daya indera, menimbulkan gairah belajar, interaksi lebih langsung antara murid/siswa dengan sumber belajar(Hafid 2011).

2. Metode

Guru sebagai pendidik harus menguasai bermacam-macam metode mengajar. Hal itu dimaksudkan agar para guru dapat melakukan pendekatan yang tepat untuk diterapkan pada tingkat perkembangan intelektual siswa Metode pembelajaran dapat diartikan sebagai cara yang digunakan untuk mengimplementasikan rencana yang sudah disusun dalam bentuk kegiatan nyata dan praktis untuk mencapai tujuan pembelajaran(Yusuf Aditya 2016).

3. Materi/Bahan Ajar

Dalam penyusunan sebuah bahan ajar tentu harus memperhatikan karakteristik bahan ajar. Karakteristik dalam penyusunan bahan ajar perlu diperhatikan dengan baik, bahan ajar yangberkualitas wajib memenuhi empat aspek kelayakan, yaitu: (1) kelayakan isi/materi kelayakanpenyajian (3)kelayakan bahasa, dan (4)kelayakan 
kegrafika(Khulsum, Hudiyono, and

Sulistyowati 2018).

\section{METODE KEGIATAN}

Pelaksanaan pengabdian program pengabdian masyarakat ini dilakukan dengan melakukan solusi yang dirancang pada solusi permasalahan dengan menggunakan kompetensi dari para anggota di bidangnya dan dibantu tim pelaksana pengabdian ini. Sasaran dari kegiatan ini adalah Sekolah Dasar Negri 36 Kota Bengkulu, berada di Jalan Kenanga 2, Kebun kenanga Kecamatan Ratu Agung Kota Bengkulu,.Detail dari metode pelaksanaan dapat diperlihatkan pada tabel 1 dan tabel 2 untuk bidang keahlian.

Tabel 1. Metode pelaksanaan program kemitraan masyarakat

\begin{tabular}{|c|c|c|c|c|c|}
\hline $\begin{array}{l}\mathbf{N} \\
\text { o }\end{array}$ & $\begin{array}{c}\text { Metode } \\
\text { Pelaksanaan }\end{array}$ & $\begin{array}{c}\text { Uraian } \\
\text { Kegiatan }\end{array}$ & Waktu & Tempat & $\begin{array}{l}\text { Penanggung } \\
\text { Jawab }\end{array}$ \\
\hline 1 & $\begin{array}{l}\text { Media } \\
\text { Pembelajaran }\end{array}$ & $\begin{array}{l}\text { Media } \\
\text { pembelajarn } \\
\text { berbentuk game } \\
\text { edukasi dan } \\
\text { media } \\
\text { pembelajaran } \\
\text { interaktif }\end{array}$ & $\begin{array}{l}\text { Minggu } \\
\text { Pertama Bulan } \\
\text { Desember }\end{array}$ & SD Negeri 36 & $\begin{array}{l}\text { Rozali toyib, } \\
\text { S.Kom, M.Kom } \\
\text { (Ketua) } \\
\text { (Tim Pelaksana) }\end{array}$ \\
\hline 2 & $\begin{array}{l}\text { Metode } \\
\text { Pembelajaran }\end{array}$ & $\begin{array}{l}\text { Metode } \\
\text { pembelajaran } \\
\text { daring } \\
\text { menggunakan } \\
\text { Google } \\
\text { Classroom/ } \\
\text { Zoom Metting/ } \\
\text { Webbex }\end{array}$ & $\begin{array}{l}\text { Minggu } \\
\text { Pertama Bulan } \\
\text { Desember }\end{array}$ & SD Negeri 36 & $\begin{array}{l}\text { Diana , M.Kom } \\
\text { (anggota) } \\
\text { (Tim Pelaksana) }\end{array}$ \\
\hline 3 & $\begin{array}{l}\text { Materi/Bahan } \\
\text { Ajar }\end{array}$ & $\begin{array}{l}\text { Bahan ajar semua } \\
\text { berbentuk digital } \\
\text { dan penggunaan } \\
\text { tutorial online } \\
\text { serta chanel } \\
\text { video }\end{array}$ & $\begin{array}{l}\text { Minggu } \\
\text { Pertama Bulan } \\
\text { Desember }\end{array}$ & SD Negeri 36 & $\begin{array}{l}\text { Muntahanah, } \\
\text { M.Kom } \\
\text { (Anggota) } \\
\text { (Tim Pelaksana) }\end{array}$ \\
\hline
\end{tabular}

Tabel 2. Bidang Keahlian Tim Pengabdian

\begin{tabular}{|c|l|l|l|l|c|}
\hline No & \multicolumn{2}{|c|}{ Nama } & Jabatan & Bidang Keahlian & Alokasi \\
Instansi Asal & $\begin{array}{c}\text { Waktu } \\
(\mathbf{h} / \mathbf{w})\end{array}$ \\
\hline 1 & Rozali Toyib, M.Kom & Ketua & $\begin{array}{l}\text { Software } \\
\text { Engineering, } \\
\text { Game } \\
\text { Development }\end{array}$ & $\begin{array}{l}\text { Program Studi Teknik } \\
\text { Informatika, FT UMB }\end{array}$ & 10 \\
\hline 2 & Diana, M.Kom & Anggota & Teknologi & Program Studi Teknik & 10 \\
\hline
\end{tabular}




\begin{tabular}{|c|l|l|l|l|l|}
\hline & & & Informasi & Informatika, FT UMB & \\
\hline 3 & Muntahanah, M.Kom & Anggota & $\begin{array}{l}\text { Multimedia \& } \\
\text { Augmented } \\
\text { Reality }\end{array}$ & $\begin{array}{l}\text { Program Studi Teknik } \\
\text { Informatika, FT UMB }\end{array}$ & 10 \\
\hline
\end{tabular}

HASIL DAN PEMBAHASAN

Pada pelaksanaan kegiatan selama 3 hari dari tanggal 23 Desember sampai 25 Desember 2020 , Acara di buka oleh MC dan selanjutnya ucapan selamat datang dari Ibu Kepala Sekolah Dasar Negeri 36 Kota Bengkulu yaitu Ibu Heny Harti, S.Pd, itu disampaikan kata sambutan Kapsek. Beliau menyampaikan tentang kondisi proses pembelajaran saat ini yang sedang susah dikarenakan Pandemi COVID19. Dalam menghadapi dunia yang sedang Pandemi, perlunya mempersiapkan diri dari sisi kemampuan sumber daya manusianya agar tidak semakin tertinggal dengan teknologi komputer dan pentingnya guru-guru untuk mengembangkan diri menghadapi situasi yang berubah dimana pada saat Pandemi ini semua serba online, pertanggung jawabannya serta perkembang teknologi yang begitu cepat menuntu guru-guru meningkatkan kemampuan khususnya komputer dan pentingnya prasarana internet disekolah.

Kata sambutan dari ketua panitia pengabdian masyarakat dari fakultas teknik Universitas Muhammadiyah Bengkulu pentingnya kreatifitas guruguru untuk membuat bahan ajar yang berbentuk video atau digitalisasi bahan ajar sehingga mudah untuk digunakan dalam pembelajaran daring serta perlunya pengetahuan guru-guru untuk bisa memanfaatkan media daring untuk memudahkan dalam belajar daring ditengah pandemic yang tidak tahu kapan akan berakhir, Untuk selanjutnya, materi oleh Pemateri satu materi yang dipaparkan tentang Sosialisai tentang Kegiatan pengajaran via online kepada para guru-guru ini maksud dan tujuan diadakan pelatihan/tutorial ini dan perkembangan komputer secara umum dan pentingnya teknologi informasi bagai setiap sektor khusunya sektor pendidikan dan pemaparan materi secara garis besar. Materi kedua Tutorial penggunaan Google Classroom, bagaimana menggunakan aplikasi daring dengan berpodoman dengan modul yang dibuat, bagai cara input data, browsing, scan data, merubah format data dan menupload data yang sudah dibuat. Pemateri dua Mengajarkan praktek 
langsung untuk browsing mencari bahan-bahan ajar dan cara mendowload dari situsnya dan menyimpan di computer pribadi, dihari yang dilakukan proses penggunaan Google Classroom sebagai mestinya.

Pemateri kedua menyampaikan bagaimana penggunaan media pembelajarn intraktif untuk menarik minat siswa untuk belajar dengan memnfaakan aplikasi yang berbentuk game edukasi, dengan begitu siswa belajar bisa lebih memahami pelajaran diajarkan serta mereka merasa tidak tertekan dalam belajar karena media belajarnya menarik dan interaktif.

Pemateri ketiga bagai mana membuat materi/bahan ajar menjadi bentuk digital sehingga mudah digunakan dalam belajar online dan tutorial pembuatan video untuk bahan ajar, dimana tatap muka tidak dimungkinkan, ada pelajaran tertentu yang tidak bisa diajarkan secara teknik book jadi penggunaan video sebagai alternatifnya.

Adapun dokumentasi kegiatan selama Pengabdian Kepada Masyarakat dan praktek Penggunaan Google Classroom di SD Negeri 36 Kota Bengkulu dapat dilihat pada gambar berikut :

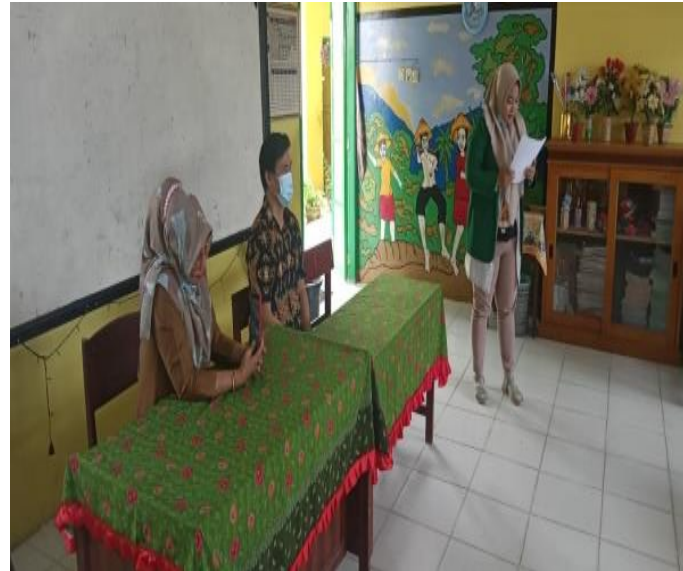

Gambar 1. Pembukaan Acara Oleh MC

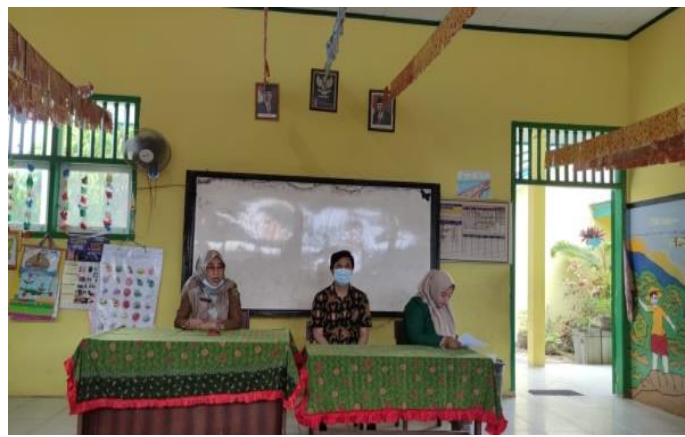

Gambar 2. Kata Sambutan dari Kepala

Sekolah

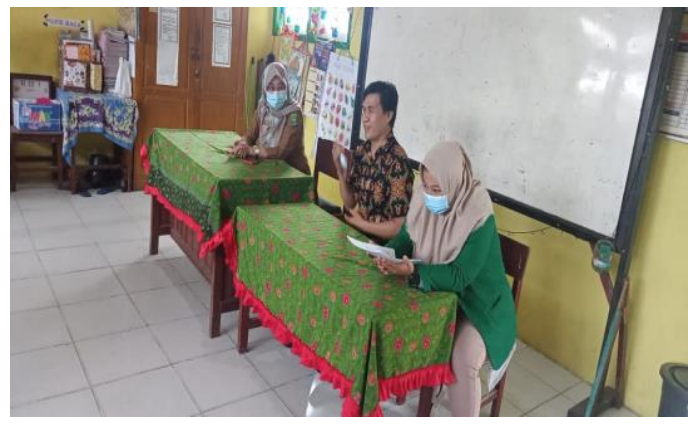

Gambar 3. Kata sambutan Dari Ketua

Panitia Pengabdian Kepada Masyarakat

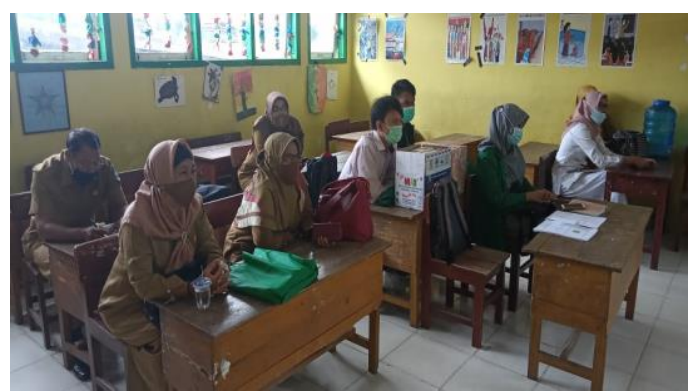

Gambar 4. Perwakilan Guru yang menghadiri pembukaan 


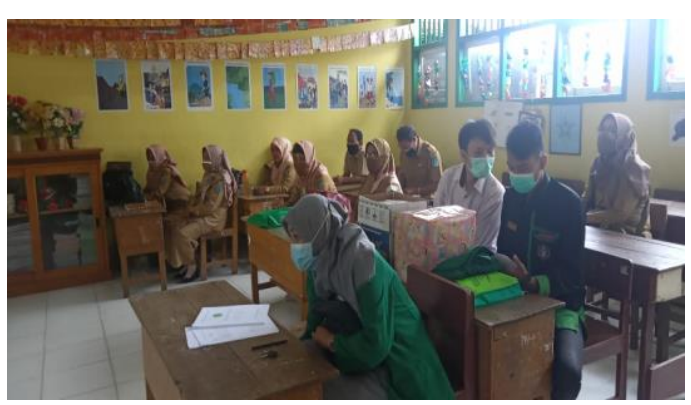

Gambar 5. Susanaan Pembukaan

Kegiatan

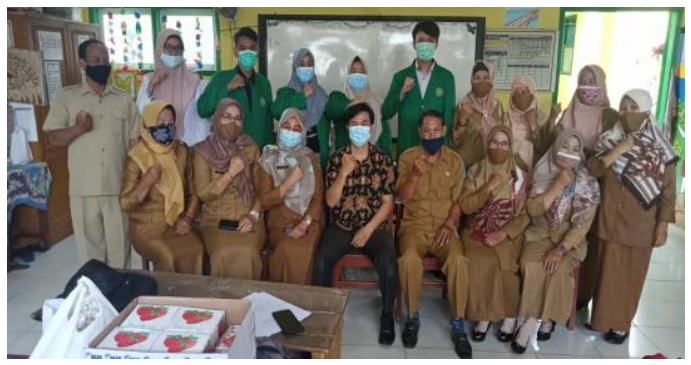

Gambar 6. Photo Bersama di Acara Sesi

Pembukaan bersama guru serta mahasiswa yang terlibat

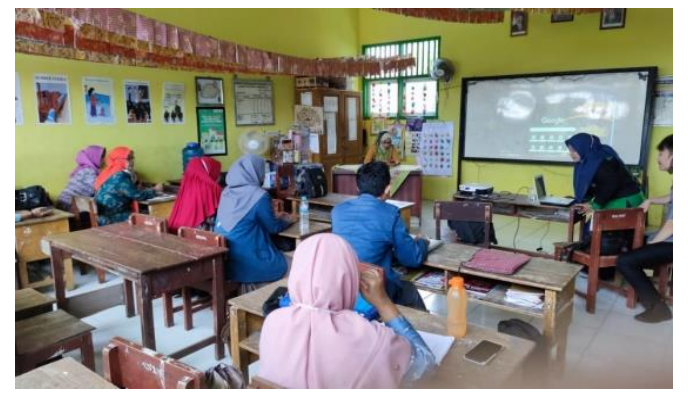

Gambar 7. Proses Sosialisasi tentang penggunaan Google Classroom

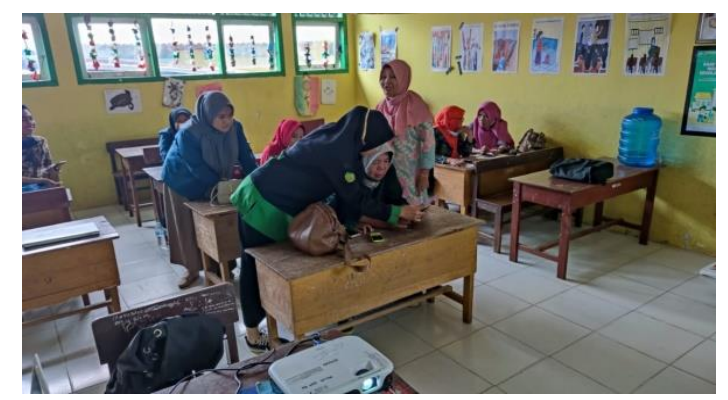

Gambar 8. Praktek Secara Langsung membuat Classroom

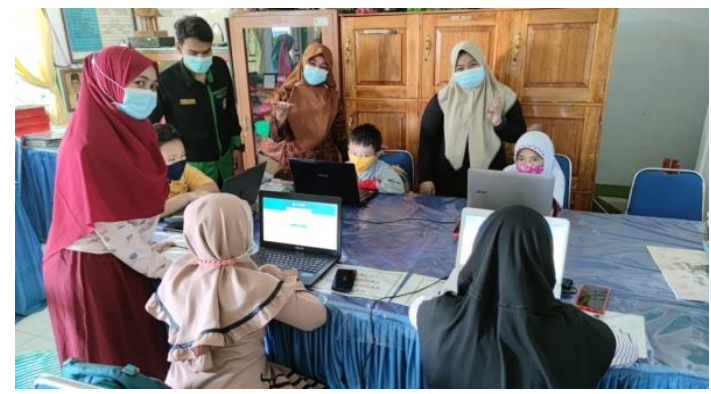

Gambar 9. Membantu proses berjalannya simulasi

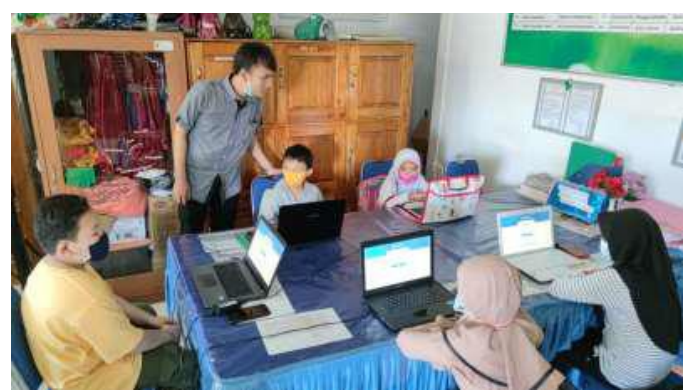

Gambar 10. Mengajari siswa yang agar bisa menggunakan media belajar online

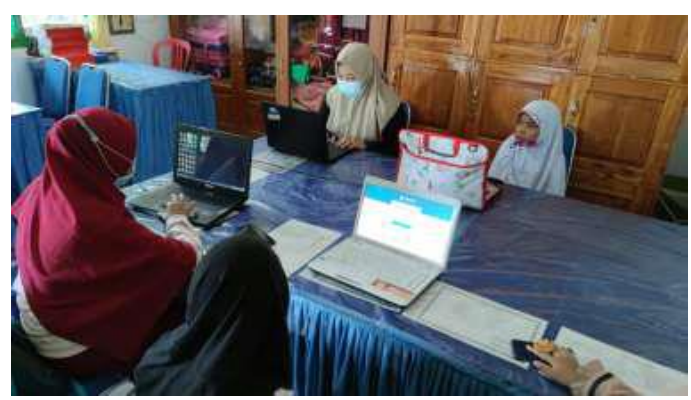

Gambar 11. Wali Siswa dilibatkan untuk mendampingi siswa belajar classroom

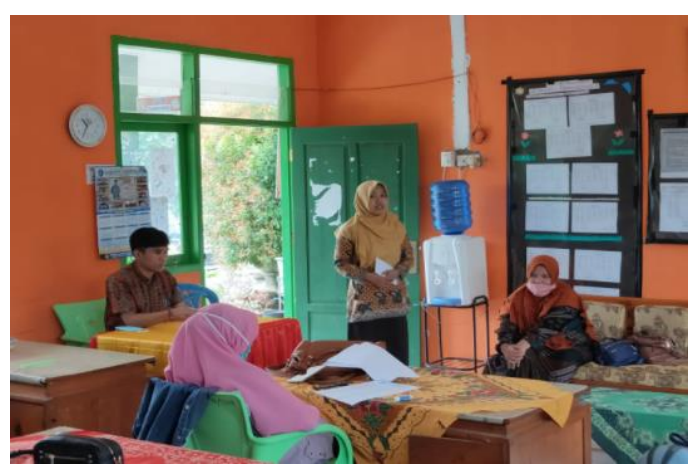

Gambar 12. Pengabdian Hari Ketiga 


\section{Ourrate}

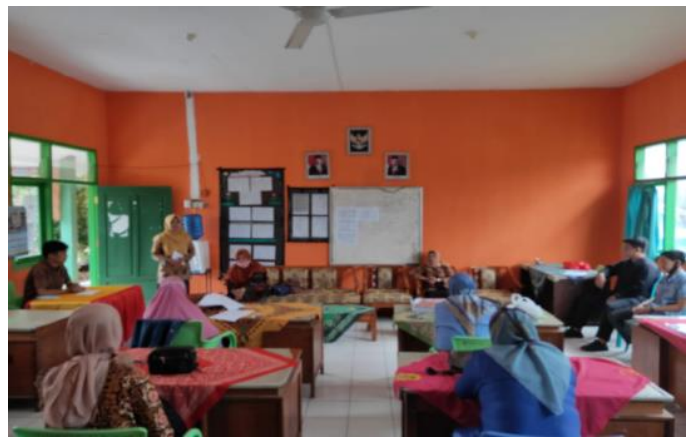

Gambar 13. Suasana Pelatihan Hari

Ketiga

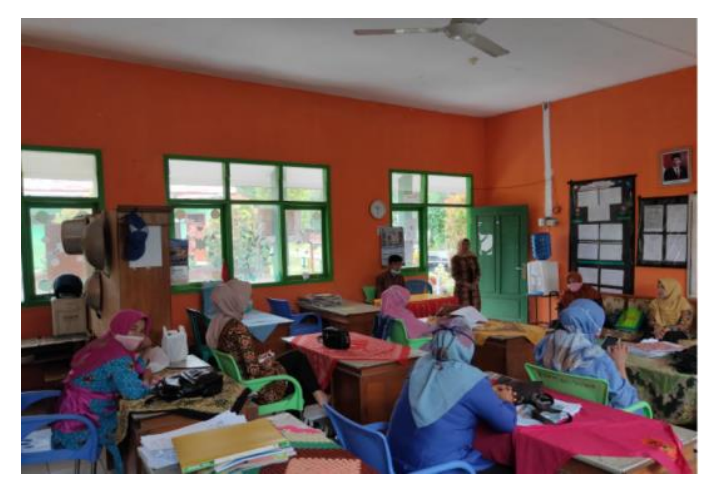

Gambar 14. Sesi Tanya Jawab

Pada pengabdian kepada masyarakat ini, hasil yang didapat bukan hanya mitra memiliki pengetahuan sedikit banyak tentang pembelajaran via Google Classroom, tahu cara melakukan laporan secara daring, bisa mecari sendiri bahanbahan ajar yang tersedia di situs yang kredibel baik berupa teks, video ataupun aplikasi bahan ajar lengkap dan perluasan jaringan internet yang bisa menjangkau semua bagian.

\section{Pembahasan}

\section{a. Partisipasi Mitra}

Mitra berpartisifasi penuh dengan menyediakan waktu, tenaga, pikiran serta menyiapkan sarana prasarana, guru, staf, ruang kelas dan fasilitasnya, serta

$$
\begin{array}{ll}
\text { p-ISSN } & 2623-2111 \\
\text { e-ISSN } & 2623-212 X
\end{array}
$$

sarana prasarana di sekolah mitra yang terkait dengan kegiatan dalam rangkah suksesnya kegiatan pengabdian kepada masyarakat ini dan antusias peserta untuk mengkuti dengan sungguh dimana hampir setiap hari pesertanya hadir dan berpartisipasi dengan mengajukan pertanyaan-pertanyaan dan memintah pemateri untuk menjelaskan lebih lanjut dari materi yang ada.

b. Langkah Evaluasi Pelaksanaan

\section{Program}

Evaluasi program pelaksanaan program dilakukan dengan maksud untuk mengetahui sampai dimana tingkat ketercapaian program yang telah dilakukan dan ingin mengetahui letak kekurangan dan penyebabnya. Dalam kegiatan pengabdian kepada masyarakat ini dilakukan evaluasi terhadap kegiatan pengabdian kepada masyarakat ini adalah dengan cara evaluasi jangka pendek dan evaluasi jangka penjang, diantaranya:

1. Evaluasi Jangka Pendek : 1) memastikan bahwa para guru (mitra) memiliki kesungguhan dan memahami pentingnya Google classroom dalam proses belajar mengajar di saat pandemi dan mau membuat hasil Metode Pembelajaran Daring via Google Classroom, pengembangan media 
pembelajaran dan pengembangan bahan ajar.

2. Evaluasi dalam jangka panjang melakukan pemantauan dalam kurun waktu 4-6 bulan untuk memastikan apa yang telah diajarkan benarbenar diiterapkan di sekolah tempat pengabdian dilakukan serta memberi tutorial dari proses pelatihan yang dilakukan.

Tabel 3. Evaluasi / Indikator Kerja Kegiatan Pengabdian Kepada masyarakat

\begin{tabular}{|c|c|c|c|}
\hline No & Kegiatan & $\begin{array}{l}\text { Waktu } \\
\text { Pelaksanaan } \\
\text { (hari/bulan ke- } \\
\text { ) }\end{array}$ & $\begin{array}{l}\text { Indikator } \\
\text { Kerja }\end{array}$ \\
\hline 1 & $\begin{array}{l}\text { Administrasi } \\
\text { kegiatan }\end{array}$ & $1-3$ hari & $78 \%$ \\
\hline 2 & $\begin{array}{l}\text { Kegiatan persiapan } \\
\text { alat dan bahan } \\
\text { (penyusunan } \\
\text { tupoksi tim, } \\
\text { pembuatan modul ) }\end{array}$ & 1-2 hari & $100 \%$ \\
\hline 3 & $\begin{array}{l}\text { Pelaksanaan } \\
\text { pelatihan/workshop }\end{array}$ & 4 hari & $100 \%$ \\
\hline 4 & Evaluasi kegiatan & $5-6$ bulan & $75 \%$ \\
\hline 5 & Laporan kegiatan & 6-7 hari & $100 \%$ \\
\hline
\end{tabular}

\section{PENUTUP}

Berdasarkan dari pengbadian masyarakat yang diadakan disimpulkan bahwa: Antusias yang tinggi dari peserta dalam mengikuti kegiatan ini dan partisifasi dari sekolah dengan meluangkan waktu dan prasarna untuk kegiatan., Aplikasi Google Classroom dan media lainnya yang tersertifikasi dengan baik dan bisa mengembangkan bahan ajar yang diperoleh di situs-situs yang kredibel serta mengimplmentasikan di sekolah, Dengan pelatihan dan pembelajaran media daring ini diharapkan dapat memberi dampak untuk perkembangan sekolah dan memperlancar tugas dari guru-guru dan staf, Sosialisasi penggunaan Google Classroom dan media lainnya dapat membantu proses Kegiatan belajar mengajar selama pandemi COVID19 dan Penyediaan prasarana yang layak untuk kegiatan ini \& penguatan Jaringan internet disekolah serta keinginan kuat dari tenaga pengajar untuk bisa mengikuti perkembangan teknologi karena sudah menjadi keharusan bukan hanya kebutuhan.

\section{DAFTAR PUSTAKA}

Ainur Risalah, W Ibad, L Maghfiroh, M I Azza, S A Cahyani, and Z A Ulfayati. 2020. "Dampak Pandemi Covid-19 Terhadap Kegiatan Belajar Mengajar Di MI/SD (Studi KBM Berbasis Daring Bagi Guru Dan Siswa)." JIEES: Journal of Islamic Education at Elementary School 1(1):10-16. doi: 10.47400/jiees.v1i1.5.

Astawa, Ni Luh Putu Ning Septyarini Putri, and Nengah Widya Utami. 2020. "Pelatihan Pembuatan Buku Cerita Digital Sederhana Sebagai Bahan Ajar Dalam Kondisi New Normal." Jurnal Karya Abdi 4(1):143-47.

Budiman, Haris. 2017. "Peran Teknologi Informasi Dan Komunikasi Dalam Pendidikan." Al-Tadzkiyyah: Jurnal Pendidikan Islam 8(1):31. doi: 
10.24042/atjpi.v8i1.2095.

Hafid, H. Abd. 2011. "Sumber Dan Media Pembelajaran.” Jurnal Sulesana 6(2):69-78.

Hakim Lukman, Dori. 2018. "UNES Journal of Community Service." UNES Journal of Community Service 3(1):11-16.

Husni, N. L., A. S. Handayani, and ... 2017. "Pelatihan Penggunaan Internet Secara Tepat Dan Sehat Bagi Guru Dan Siswa Di MTS ArRahman Palembang Guna Meningkatkan Kreativitas Serta Kesadaran Guru ..." ... Research Seminar (ARS ... 3(1):127-31.

Indah, Qurnia, and Permata Sari. 2021. "Coaching Online Pembelajaran Jarak Jauh Bagi Guru Sekolah Dasar."

Jaelani, Ahmad, Hamdan Fauzi, Hety Aisah, and Qiqi Yulianti Zaqiyah. 2020. "PENGGUNAAN MEDIA ONLINE DALAM PROSES KEGIATAN BELAJAR MENGAJAR PAI DIMASA PANDEMI COVID-19 (Studi Pustaka Dan Observasi Online)." Jurnal IKA PGSD (Ikatan Alumni PGSD) UNARS 8(1):12. doi: 10.36841/pgsdunars.v8i1.579.

Khulsum, Umi, Yusak Hudiyono, and Endang Dwi Sulistyowati. 2018. "Pengembangan Bahan Ajar Menulis Cerpen Dengan Media Storyboard." Diglosia 1(1):1-12.

Pudjianto, Udik, Anang Kukuh Adisusilo, Lestari Retnawati, and Nia Saurina. 2020. "Peningkatan Kompetensi Tenaga Pendidik Muslimat $\mathrm{Nu}$ Surabaya Dalam Penguasaan Teknologi Informasi Dan Komunikasi (Tik)." Adimas : Jurnal Pengabdian Kepada Masyarakat 4(1):22. doi: 10.24269/adi.v4i1.2026.
Putra, Guntur Maha, Novica Irawati, and Adi Prijuna. 2019. "PELATIHAN BLOG SEBAGAI SARANA PUBLIKASI PEMBELAJARAN GURU SMA NEGERI 2 KISARAN Guntur.” 2(2):145-52.

Setiawan, T. H., A. Aden, and ... 2020. "Pelatihan Daring Teknologi Pembelajaran." JPKM-Aphelion (Jurnal ... 01(01):37-47.

suharto. 2012. "Pengembangan Materi Dan Kegiatan Pembelajaran Dalam Kurikulum Tingkat Satuan Pendidikan Bidang Seni Musik." An-Nida' 37(1):27-35.

Sunarsih, Denok, Hadion Wijoyo, and Fikron Al Choir. 2020. "Implementasi Pembelajaran Online Dalam Masa Pandemik Covid 19." Prosiding Seminar Nasional Lembaga Pengembangan Pembelajaran Dan Penjaminan Mutu 2020 46(0):411-16.

Tulili, Tien Rahayu, Yusni Nyura, Wahyuni Eka Sari, Dosen Jurusan, Teknologi Informasi, and Politeknik Negeri. 2018. "Pelatihan Pembuatan Bahan Ajar Berbasis Multimedia Bagi Guru Di Kota Samarinda." 2018:191-96.

Yusuf Aditya, Dedy. 2016. "Pengaruh Penerapan Metode Pembelajaran Resitasi Terhadap Hasil Belajar Matematika Siswa." SAP (Susunan Artikel Pendidikan) 1(2):165-74. doi: 10.30998/sap.v1i2.1023. 